\title{
Guinea-Bissau (2014 - 2016). An empirical study of economic and social human rights in a fragile state.
}

\author{
Carlos Sangreman \\ University of Aveiro. Center of Studies on Africa, \\ Asia and Latin America of the University of Lisbon. \\ Fátima Delgado \\ Association for Cooperation among Peoples (ACEP), \\ NGO, Lisboa \\ Luis Vaz Martins \\ Guinean Human Rights League, Bissau
}

\begin{abstract}
The purpose of this article is to analyze the situation of the economic and social human rights in Guinea-Bissau. It uses data collected from seven of the eight administrative regions of the country between 2014 and 2016, for a project called "Observatory of Rights" in the fields of education, health, justice, housing, sanitation and livelihood from schools, health centers, jails and police stations and families. With 5 prime ministers since the elections of 2014 , the political instability installed in the country shapes the life of citizens in all aspects and does not allow a positive evolution of economic and social human rights in the country.This article frames the analysis of the data into an interpretation of the situation of that period and elaborates the conclusions in the form of scenarios for the short-term future, including the possibility that the military might decide to take power as they have done in the recent past (2012).
\end{abstract}

Keywords: West Africa, Economic Human Rights, Social Human Rights, Guinea-Bissau

\section{INTRODUCTION}

The object of analysis in this article is the economic and social human rights of the people in a fragile country of West Africa - the Republic of Guinea-Bissau - through the data collected between 2014 and 2016 from seven of the eight administrative regions for a project called "Observatory of Rights" funded by the European Union and by Camões the Portuguese cooperation Institute and executed by a local Human Rights organization - the Liga guineense dos Direitos Humanos (LGDH), a Portuguese NGO - Associação para a Cooperação entre Povos (ACEP) and a research center of the University of Lisbon (CESA) in the fields of education, health, justice, housing, sanitation and livelihood. The context of institutional and political instability in this country, during the period analyzed, is intended to convey a reality that is difficult to understand for external spectators or even for many of those who have been interviewed inside the country. Guinea-Bissau is classified as a fragile state, with institutional instability, low-general literacy, exposed to various types of trafficking such as drugs or children, and influenced by religious fundamentalists who claim to be of Muslim origin. These characteristics are present in many preponderance aspects of Guinean social and political life, but at the same time of freedom (in particular, of politics and the press) and respect for organized civil societies, do not fit into the typologies presented by the international organizations that estimate fragility indices. 
In this way, we seek to make a contribution to the understanding of societies in fragile states by using Guinea-Bissau as a model to show how they continue to live and even evolve with many years of permanent chaotic institutional instability and how they integrate this situation into a daily commonplace. The international investigation on Guinea-Bissau is significant for the size of a country with small population, unstable governance and which the economy is based on agriculture and fishing, without rapid-income resources such as oil, diamonds, gold or precious minerals. However questions for which there are no answers within the standards of other countries come about. Ceesay, H. [4], has two pages on the research on Guinea-Bissau and asserts in page seven, "In spite of everything, as Chabal and Daloz would have put it, "Guinea-Bissau works" and the key questions to be answered are how, why and what it means."

This research can be included in Wiktor Osiatynski's [11] theses on the limits of first generation human rights (political and civil), arguing that the data collected indicate that the central concern of governance is increasingly economic and social rights and less Political and civil rights that without military interventions tend to evolve positively despite the present chaotic characteristics.

\section{Guinean society - the evolution in permanent instability Structural components}

In order to try to understand the instability that has taken root in everyday life since 2014, we will start by retaking the structural components of Guinean society that Sangreman, C., Junior, F., Zeverino G. e Barros, M.[1], considered:

The first well-analyzed point by Lopes C. [8] - the long-term base element - is related to the formation of kaabunké territory. This included part of what is today south Senegal and north Guinea-Bissau and as stated by Lopes, C. [8] "The Kaabu ..., is the result of an inheritance of centuries and not of only a couple of years. It is a fundamental element to interpret the interactions of different (ethnic, social and class) groups in Guinea-Bissau, Gambia and Casamance"(our translation). Likewise, actions aimed at helping people across the border are the object of a social consensus that goes beyond the reasoning used to form the relations among states. It crosses several social levels from the neighbors of the same ethnic group to the reasoning used to support the rulers of the movements or politic parties that demand the independence from Senegal and the armed assistance provided to one of intervenient in the 1998-99 civil war in Guinea-Bissau.

The second medium-term base component is related to the formation of the Guinean State from Portuguese colonialism and the armed-fight led by the African Independence Party of Guiné and the Cabo Verde Islands (PAIGC). This party, being a movement of national liberation, exerted a leadership in the fight for the independence by choosing three objectives that could mobilize the population for the support they needed: 1 - independence; 2- development; 3- the unity of everyone who lived in the territory colonized by the Portuguese, without questioning the colonial borders and fighting against tribalism. Of these objectives, the third refers directly to the national identity. Cabral [3], considered "whatever the ethnic group, it is easy to get people to consider that we are a people, a nation, ...", "what remained of tribalism has been destroyed by the armed-fight we led.". "Only political opportunists are tribalists"(our translation). It should be noted that other members of the PAIGC leadership did not have the same view of ethnic cleavages. Manuel dos Santos, still leader of the PAIGC, affirmed: "The armed-fight for national liberation has promoted a certain degree of unity among the people of Guinea over a common goal, - the fight against Portuguese colonialism - created important bonds of solidarity and interdependence among different groups but, on contrary to what many people affirm, it has not realized the national unity, nor has it generated the Guinean nation. It has 
constructed its bases and the foundations for the Nation, and created the necessary but not sufficient conditions for its appearing" (Santos [12]) (our translation).

Regardless of the position taken by the leaders in the fight and the construction of the Guinean Nation and State, everyone considered the cleavages of ethnic origin as enemies of this process. We add a third component that derives from what Forrest, [5], calls "Praetorian social memory" formed from the resistance against the colonial conquestii, to the victory in the colonial war of 1961-1974 and the 1998/99 war against the military forces of Senegal and Guinea Conakry sent to the help President Nino Vieira forces. In other words, the well-known story of Guinea-Bissau has a narrative of victories or heroic resistance which created a "warrior" component of positive intervention by the armed forces in the country's future. iii Such component has diminished its social importance with successive coups since November 14th, 1980, reaching the current situation of the military being accused of being the main source of instability until 2014. But it is a component that continues to have weight although, in the present day, it depends more than ever on political leaders, especially from PAIGC.

The fourth structural component is about the thirty two Guinean ethnic identities numbered by the national census 2009 (Ministério da Economia, do Plano e Integração [10]). The study was mainly carried out by Portuguese and Cape Verdean researchers of colonial times - available at http://memoria-africa.ua.pt/ - and a few Guinean, American and European afterwards. Same serious research into the actuality of the ethnicities as a whole is necessary for Guinean society to realize what its structural component is today, even so Cardoso [2] is right to state that "the process of ethnic-cultural and civilizational miscegenation does not allow us to speak of any ethnicity or ethnic identity that we can consider pure"(our translation) (Cardoso, 1996). The references of Chabal, P. and Green, T. [7], is the most current source for research in nonPortuguese language.

The fifth structural component regards the resilience of the Guinean population, with aspects of anti-fragilityiv. With the admiration of Green (Chabal and Green [7], 7) "Guinean daily life remains peaceful, in contrast to the stereotypical image of the country, and people often cooperate and marry each other "ethnic divisions" ... "as some researchers suggest about Somalia" there are states that can function better without an institutional structure than those where the public management is operational. The population, having sufficient food production (rice, fish, fruit, poultry, swine and cattle) has developed a pliancy that deteriorates as the energy (lights, refrigerators, TV, mobile phones) and the improvement carried out in schools broaden the horizons for defining the standard of living to which the population aspires. In this way, people become less tolerant in the absence of such conditions. For now, the recent history shows that the country works in any situation, not wanting such pliancy means resignation. For better or worse, but far from the conflicts experienced by others in the sub-region such as Liberia, Sierra Leone or even Guinea Conakry.

\section{Social Groups}

Guinea-Bissau is a country composed of multiple social identities that intersect and overlap each other. From the base of the ethnic identities, the social groups, that were formed in the cities where the colonial presence was stronger, joined. Ethnic reading of the social reality of the country arises whenever the situation is complex, although the parties never stick to it, not even the Social Renewal Party (PRS) that from its beginning was accused of being a party of balanta ethnic majority like their historical leader Kumba Yalav. The religiousvi reading is less evident, although the President of the PAIGC felt the need to justify the secularity of the State and to affirm that it is not because he is Christian that this religion should be privileged. After independence, an identity of former combatants (or veterans) of the liberation fight was 
formed, with a mixture of Guinean and Cape Verdean ethnic backgrounds, with very different levels of income and with a strong presence in the public institutions and in the general Guinean political life. Like any other country with independence movements, their social status is transmitted to the descendants which contributes to the growing of the group even with the deaths of those who had previously fought. Economic actors such as ship owners, traders, small or medium-sized entrepreneurs, simple importers of consumer goods, farmers or loggers with a production oriented towards the internal market or exportation, form a social group united by the need to have the best conditions to succeed and secure the direct support provided by the State through subsidies, purchases and contracts whenever possible. This group used the banks' credit facilities to create a lump-sum credit. According to a speech from the head of the Banque Central des Etats de l' Afrique de l'Ouest (BCEAO) at a business conference in Bissau in July, 2016, at the time of the 2014 elections, in general, the Guinean bank had already gone bankrupt with a long list of significant individual economic actors and country firms debtors (which announcement has been claimed by PAIGC). This group generally has difficulty at competing with equivalent groups in other countries even if they share borderlines. These economic actors have been participating in political life and it is now clear that there are congressmen and party members that defend their interests.

Also, there is a last and smaller social group with a high level of education, made up of two subgroups: the first is composed of elements of civil society that are integrated in NGO or similar organizations with some autonomy like the Universities and National Research Center (INEP) and with international organizations that have a strong relationship with foreign and multilateral financiers, which have a significant importance, due to the absence or instability of public structures. Their identity is more cosmopolitan than the majority of the population and they participate in political life on their own logic, that means that many members do not want to be neither too close nor too far from the most important decisions. The second subgroup are composed by the members of the formal parties that were raised in or born with the country being already independent and having Guinean officials of the international organizations. Together with the first subgroup they form the intellectual elite of the country.

\section{Why the prevailing instability?}

Our interpretation heads to two logics that dispute for power. The first is about the political relations patterns between the presidency and the other institutions of sovereignty. The Guinean system of government is semi-presidential with a parliamentary inclination and absolute separation of powers - "it is not for the president of the republic to judge the goodness of this device, it is a reflection of the sovereign wish of the Guinean people" (PAIGC communiqué s.d.). But the practice of two of the holders, elected in general elections endorsed by observers, of the presidential portfoliovii (Nino Vieira e Kumba Yalá) has always been to perform the position as if they were chiefs of the executive power. The current president João Mário Vaz (Jomav) is the first president elected who finds it difficult to continue that model because he is faced with a prime minister and chairman of the most voted Party who performs the functions of two institutions - presidency and government - differently, closer to parliamentarism rather than semi-presidentialism, in a model of permanent balance of powers that resulted from the debate of ideas and solutions to economic and social policies within parliament National Popular Assembly (ANP) and in respect for electoral results.

The second logic in this power dispute is the dominant role of political power at regulating the country's economic relations and access to the funds promised by the international community in Brussels in 2014. The options of the new PAIGC leadership lead to a decrease in economic liberalism, to a greater regulation on the so-called state of profit-generating activities, to the respective collection of taxes, and to retake some ideas of the central planning post- 
independence but now in context of free and regulated market, aiming at increasing public revenue from internal sources.

We think that these two logics are beyond the parties themselves and they lead to dissidence in the PAIGC and in the main opposition party, the Party of Social Renovation (PRS).

The interaction between the social groups that dispute the political power (first logic) and the economic power (second logic) was radicalized mainly after the appointment of a Government in May of 2016 by the President himself. From April/May on, Party leaders have joined to make accusations, ranging from participation in contracts of illegal fishing and logging to misappropriation of funds and abuse of power, against the president. Four of the five Parties with parliamentary representation, the main player who leads and configures all these events is João Mário Vaz (Speeches given in the celebration of the Independence Day, September 24 of 2015).

With the military reassigned to their constitutional functions of ensuring the country's security and independence, the conflicts between the executive, legislative and presidential powers resulted in giving significant leverage to court decisions, therefore the Supreme Court of Justice was summoned to define whether it was conformed or not with the Constitution and with the law of several acts of the institutions of sovereignty.

This is the interpretation we make about the context in which we have investigated. Now we analyze the access to Economic and Social Human Rights.

\section{The legal framework of Human Rights in Guinea-Bissau}

Guinea-Bissau adopts in its constitution that Human Rights are part of the internal law of the State by incorporating the Universal Declaration of 1948 as its national legal framework. The most recent reference documents are the country review, conducted in 2009 by the UN Human Rights Council, and the three reports of the Guinean Human Rights League (2008, 2012 and 2016). Furthermore, there are studies, some more in-depth than others, about social groups such as women - "A portrait of violence against women in Guinea-Bissau", by Sílvia Roque and five other researchers, 2011, UNWomen, UNPopulation Fund, UNDevelopment Programme and UN Integrated Peace building Office in Guinea-Bissau - or the Children - various studies by NGO, UNChildren's Fund and International Labor Organization on trafficking of children who are sent to Senegal to learn the Koran in slavery conditions - the talibés -, child labor, sexual abuse and exploitation. Thus, Guinean legislation explicitly consecrates the legal framework of sentences against women violence (female genital mutilation, domestic violence, early and forced marriage) along with rape, sexual abuse and trafficking. It also consecrates civic and political freedom along the lines of the first generation of human rights, as well as the rights of children, especially the defense against trafficking of children for sexual exploitation or forced labor. It should be noted that the phenomenon of child labor is still very little addressed in Guinean legislation. Although Yasmine Cabral [14] states that "Nevertheless the recognition and incorporation of the main international and regional human rights instruments, particularly the International agreement on Civil and Political Rights, the International agreement on Economic, Social and Cultural Rights, the agreement on the Elimination of all forms of prejudice against Women, the agreement on the Children's Rights, the African Charter Protocol on the Women's Rights, and the African Charter Protocol on Children's Rights and Welfare in Africa" (our translation) the country continues to face difficulties to put the content of these documents into practice. As it can be seen from the three reports of the Guinean League for Human Rights or from international reports, that the Human Rights of Civic and Political Freedom are still constantly being violated with military intervention, especially in times of instability. Only after 
the 2014 elections the military force stopped intervening in the country's politics. The remaining generations of Rights have a great precariousness depending on the comparison standards used. But even if we focus only on the sub-region of Senegambia, as a matter of comparison, the existing indicators for the remaining countries demonstrate that the right to health, education, human safety, etc., are generally poorly ranked in Guinea-Bissau.

\section{METHODOLOGY}

In organizing a data collection structure it must be considered that people in general do not have a substantial statistical culture. In other words, they do not have a concern about the accuracy of collected information always in the same way and from the same sources. The poor quality of Guinean education has also not helped to deal with the numbers or with simple measurement principles, so it implies that the notion of statistical production does not exist in the inquirers, and that their training in basic mathematics is weak.

The Observatory's direct team in the collection of data consisted of two national statistician experts, and 12 inquisitors selected by the Guinean League for Human Rights (LGDH), from people in different regions who have some connection with human rights activities.

In the collection process of the first year the numbers collected were evaluated, on the baseline scores of zero-twenty to the interviewers, and it has been found that it was possible to have a process of continuous improvement of those who had more difficulties, through the initiative of the referred technicians and through more detailed discussions with CESA experts, reaching a very good level in the last collections of that year, which has continued on the following period.

The propagation and motivation of the respondents in the various regions are fundamental in a project that has national goals. As a result, annual reports in the form of a book were delivered to organizations and to key people as informants. Annual exhibitions open to the public, showing the results, including discussions with the inquirers and in some cases with members from the general coordination of the project, have been organized in the regions. In using graphics and charts, attractive graphics on color-coded transportable panels with a resistantscratch handling; the inquirers, people from settlements in the countryside, have been cherished by seeing the results of an inquiry to which they had responded to.

The indicators were chosen based on the United Nations Office of the High Commissioner for Human Rights [16] classified in Structural Indicators, processes and results in the areas of Security, Food, Health, Justice, Governance, Education, Housing and Sanitation, Water, Labor, Social Security, Freedom, Gender, Discrimination and Life in debates with the presence of all inquirers, focusing on the difficulties, doubts and solutions adopted in the collection and statistical managing of collected data.

We then had the following indicators:

\section{Education}

1. School attendance per elementary school, sex gender in a village or neighborhood at the beginning and end of the school year.

2. Number of students per teacher in a school in a village or neighborhood at the beginning and end of the school year.

3. Average distance between the place of residence and a school, where there is basic education provided by a village or a neighborhood. 


\section{Health}

4. Distance between the place of residence and a place, where it can perform a prenatal exam.

5. Cost of the first prenatal exam (pass, analysis and examination) in a location, where there is this availability.

6. Cost of five different medicines (malaria, fever, diarrhea, soreness and infant hydration).

7. Cost of appointment, examination/analysis, medicines and serum for severe malaria (three or more levels).

8. Health personnel per hospitals, centers or basic units in a region (doctor, nurse, midwife, health assistant and community health workers).

\section{Housing}

9. Number of people per room, in a village or neighborhood.

10. Number of houses where there can be seen improvements, per village or neighborhood.

\section{Potentially processed water}

11. Number of traditional improved wells with pump running and piped water per village or neighborhood.

\section{Energy}

12. Number of houses with access to electric lamps powered by energy from any source, at night (electric grid, generator or solar panel), per village or neighborhood.

\section{Sanitation}

13. Destination of household waste.

\section{Justice}

14. Distance from the housing to a first-instance court.

15. Area of cells per number of imprisoned people by sex gender and incarceration center.

16. Area of cells per number of imprisoned people by sex gender in prison.

17. Conditions of cell areas in incarceration centers (ventilation, dormitory, roof and access to water and food).

18. Entity whom people believe to solve cattle theft (traditional, police or court).

\section{Livelihood}

19. Number of home daily meals in the family.

The sensibility of state-owned and civil entities for giving the data was made in Bissau and in some regions during 2014. It has been kept on in the remaining two years by the coordination of the Observatory and, in some cases, by LGDH management, especially with the help of school, sanitary and police authorities. When necessary, it was possible to obtain authorizations from general directors, secretaries of state and ministers so that the inquirers would have access to the sites needed in order to gather the information.

As a working tool for data collection, the project assigned to each inquirer a computer, a camera and a motorcycle. Today, the hundreds of photographs taken by the inquirers are the best description of the good and bad conditions of schools, health centers, incarceration cells, etc. In this way, completing the quantitative information collected.

Lastly, it should be noted that the inquirers, the two assistant technicians and the coordination were always national, average-aged people with relatively high qualifications. Some 
of them have been teachers, which helps with the reliability and the responsibility for the collection of information. The analytical data capacity remained throughout the project dependent on international technicians.

There has been some gender imbalance in the team, since only the 2015 and 2016 coordinators and one of the inquirers were women. Ten inquirers and two technicians were men. Even in the north region of Gabu the inquisitor, who passed away, had been replaced by a man who used to be her data-gathering helper. The truth is that the need for motorized journeys through inland dirt roads does not facilitate the inclusion of women, but it was found that for some of the indicators, especially in the area of health, male inquirers had more difficulties in collecting data than female inquirers.

As the indicators were collected by each region, a question, related to predicting the construction of a national index based on regionalized information, arose. The methodology of this index has the following initial points:

1) All areas have the same significance in the formula for synthesis calculation.

2) The areas (Education, Health, etc.) are weighted by the number of indicators collected. That is, it is considered that, the more indicators collected, greater will be the knowledge about the human rights area and therefore the greater the reliability of the synthetic data produced. No quality judgment is made however such a confidence judgment in the indicators is present.

3) The scales to be used should be the same for all indicators and vary in the same direction. In other words, when the numbers increase or decrease, the meaning in all indicators must be whether improving or worsening the rights this indicator wants to portray.

4) All indicators are reduced to the one-eight ranking scale from the best (one) to the worst (eight) of human rights access. The ordering value is assigned from the best to the worst, repeating the values if the results are the same.

5) The components of each indicator have a specific scale and/or weight corresponding to the base formulation referred to in point (6).

6) Mathematical formulation:

a. $\quad N I$ being the indicator number $=1,2,3,4,5,6,7,8,9,10,11,12,13,14,15,16,17,18$.

b. $E$ being the assortment scale $=1,2,3,4,5,6,7,8$.

c. In conglomerate indicators (e.g. conditions of incarceration centers) the basic aggregation formula is $\sum \mathrm{e}=1-8$, which comes back to normal in the scale one-eight the result of the sum.

d. Significance of areas: Education $=5$; Health $=5$; Housing and others $=4$; Justice $=$ 4; Livelihood $=2$.

e. Final formula for each region:

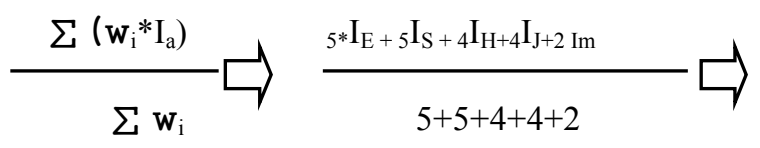

with $\mathrm{w}_{\mathrm{i}}=5,5,4,4,2$

$\mathrm{Ia}=$ Education, Health, Housing and Others, Justice, Livelihood

$\mathrm{R}=$ Bafatá, Biombo, Cacheu, Gabu, Oio, Quinara, Tombali, Autonomous Sector of Bissau (SAB)

\section{CASE HISTORY}

In the first year the experiment was defined as being geographically based. In other words, institutions from all regions were surveyed, except Bolama/Bijagós islands because they have not been considered in the initial project due to the increase in the budget, and within each 
region the sectors with the most population were selected according to the last Population Census of 2009. Within each sector, the localities were chosen by prioritizing the most populous ones, and allowing some flexibility so that the interviewers could replace people if the reception and contact within the institutions did not allow the collection of information. It was indicated to inquire at least 10 percent of existing schools and health centers in each sector, by maintaining the minimum of one institution per locality if it existed. In general, the inquirers in the regions exceeded this percentage.

In the capital, Bissau, there are eight administrative sectors; however, people know the city by neighborhoods, not by sectors and the census data is also surveyed by neighborhoods, sectors and census districts. The most populated neighborhoods were chosen according to the work capacity of the inquirers. As for the census data, they correspond to 70,8 percent of the population counted in the SAB. It is not correct to adopt population projections made only bases on rates of census evolution, less likely when data are intended for the regions where the country is divided. The processes of civil registration of births and deaths are not reliable, they ignore a) the number of children who do not enter the school system, b) migrations, especially those realized through land or sea into the countries of the sub-regions, c) internal migrations from the rest of the country into the capital, and d) the distribution of internal and external migrants by Bissau neighborhoods. Only the results of the 2009 census should be considered as reliable. Such an option means that the use of the population data sorted by region in the construction of indicators includes a deviation from reality that cannot be calculated unless the next census is carried out. In our indicators, this deviation is important in the area of health in the indicator of number of people per doctor/nurse/midwives and other professionals.

In the second and third year 5 percent of the locations to be surveyed were defined as the experiment in all sectors, all policeviii incarceration centers and the two prisons in the country, at least one school in each locality, neighborhood and health center/basic health unit (always with a minimum of 1 locality per sector or neighborhood), and a maximum of fifty houses, except if the number of those placed on the main street was lower, per locality.

Table 1 - Localities surveyed in 2016

\begin{tabular}{|l|l|l|}
\hline Purpose of the Inquiry & percent & Number \\
\hline Localities without Bolama/Bijagós Census 2009 & 100 & 4245 \\
\hline Education surveyed localities & 6,2 & 262 \\
\hline Health surveyed localities & 5,1 & 218 \\
\hline Housing, energy and water surveyed localities & 5,0 & 214 \\
\hline Justice surveyed localities & 5,4 & 230 \\
\hline Livelihood and sanitation surveyed localities & 10,5 & 447 \\
\hline
\end{tabular}

Source: Observatory of Rights, 2016 and Census 2009

Concerning the number of households and inputs for the indicators of livelihood and sanitation, the percentage of 5 percent would give a workload incompatible with the existing budget, with a total of 9.063 households to be surveyed. Thus, it was decided to inquire an aggregate structure of households which would approach the national aggregate structure, but with numbers compatible with the project budget. As a result, the household numbers ranged from one hundred to fifty in the regions according to the population census in 2009 . For the $\mathrm{SAB}$, the number of household surveyed were the same used for the family budget survey that the National Institute of Statistics of Bissau executes, from twelve per neighborhood. 
The households to be surveyed were specifically chosen by: a local indication of households with permanent residence (according to the definition of the Census); and the definition of family as - the head of the family person - indicates it and not by housing numbers of the household. In other words, families that are defined as such are chosen because they have meals together regardless of the degree of kinship in the dwellings they use, if they have at least one permanent residence.

A gross case history rate was calculated based on the existing and surveyed sectors and districts:

Table 2 - Case history

\begin{tabular}{|c|c|c|}
\hline Existing Regions and Sectors & $\begin{array}{l}\text { Regions and sectors where data } \\
\text { has been collected }\end{array}$ & Case history rate \\
\hline $\begin{array}{l}\text { BAFATÁ (Bafatá, Cossé, Bambadinca, Xitole, Contuboel, } \\
\text { Gã-mamudo(Ganadu)) }\end{array}$ & $\begin{array}{l}\text { Bafatá, Cossé, Bambadinca, } \\
\text { Xitole, Contuboel, Gã- } \\
\text { mamudo(Ganadu) }\end{array}$ & $\begin{array}{l}6 / 6(100 \\
\text { percent); }\end{array}$ \\
\hline BIOMBO (Quinhamel, Safim, Prabis) & Quinhamel, Safim, Prabis & $\begin{array}{l}4 / 4(100 \\
\text { percent); }\end{array}$ \\
\hline BOLAMA/BIJAGÓS & No data has been collected & n. a. \\
\hline $\begin{array}{l}\text { CACHEU (Bigene, Bula, Caió, Canchungo, Cacheu, } \\
\text { S.Domingos) }\end{array}$ & $\begin{array}{l}\text { Bigene (only the 10 year) , Bula, } \\
\text { Caió, Canchungo, Cacheu, São } \\
\text { Domingos (only the sector } \\
\text { capital and Ingoré) }\end{array}$ & $\begin{array}{l}5 / 6(83,3 \\
\text { percent) in the } 1^{\circ} \text { - } \\
\text { year; } 5 / 6(83,3 \\
\text { percent) in the } 2^{\circ} \\
\text { and } 3 \text { o year }\end{array}$ \\
\hline GABÚ (Boé, Pitche, Gabú, Pirada, Sonaco) & $\begin{array}{l}\text { Boé, Pitche, Gabú, Pirada, } \\
\text { Sonaco }\end{array}$ & $\begin{array}{l}5 / 5(100 \\
\text { percent); }\end{array}$ \\
\hline OIO (Bissorã, Farim, Mansaba, Mansoa, Nhacra) & $\begin{array}{l}\text { Bissorã, Farim, Mansoa, } \\
\text { Mansaba }\end{array}$ & $\begin{array}{l}4 / 5(80 \text { percent }) \\
\text { in the } 1^{\circ} \text { year; } \\
5 / 5(100 \\
\text { percent) in the } 2^{\circ} \\
\text { and } 3^{\circ} \text { year }\end{array}$ \\
\hline QUINARA (Buba, Empada, Fulacunda, Tite) & Buba, Empada, Fulacunda Tite & $\begin{array}{l}4 / 4(100 \\
\text { percent })\end{array}$ \\
\hline TOMBALI (Catió, Komo, Bedanda, Cacine, Quebo) & $\begin{array}{l}\text { Catió, Komo, Bedanda, Cacine, } \\
\text { Quebo }\end{array}$ & $\begin{array}{l}5 / 5(100 \\
\text { percent })\end{array}$ \\
\hline $\begin{array}{l}\text { Setor Autónomo de Bissau (SAB) [Militar, Antula(Bono), } \\
\text { Quelele, Bandim2, Plak2, Reino, Madina, Cuntum, Pessak, } \\
\text { Belém, Cupelom de Cima e de Baixo, Bandim1, Missará, } \\
\text { Plak1, Empatcha, Luanda, Brá, Hafia, São Paulo, Penha, } \\
\text { Djolo, Bissaque, Melhoramento, Internacional, Ajuda } 1 \text { a } \\
\text { fase, Djogoro, Massa Cobra, Tete, São Vicente Paulo, Santa } \\
\text { Luzia, Sintra Nema, Pluba de Cima e de Baixo, N’ Dame, } \\
\text { Lero, Lala Quema, Flefe, Rossiu, Calequir, Amedalai, Ilheu } \\
\text { de Rei, Varela, Tchada, Setembro, Mindara, Chão de Papel] }\end{array}$ & $\begin{array}{l}\text { Militar, Antula(Bono), Quelele, } \\
\text { Bandim2, Plak2, Reino, Madina, } \\
\text { Cuntum, Pessak, Belém, } \\
\text { Cupelum de Baixo e de Cima, } \\
\text { Bandim1, Missará, Plak1, } \\
\text { Empatcha, Luanda }\end{array}$ & $\begin{array}{l}16 / 45(70,8 \\
\text { percent of } \\
\text { population })\end{array}$ \\
\hline
\end{tabular}

In this way of arranging the case we have, in fact, several types of case history divided into two large groups: the case of conglomerates (schools, health centers, incarceration centers) where institutions, in finite and small numbers are surveyed, but always with a higher national number than the numbers indicated in the statistical theory ( $\geq 30$ or $\geq 100$ ) and random cases for localities, housing and households.

We can also calculate 95 percent of confidence intervals, considering both the "normal" universe and case history distributions (See Sangreman, C.[12]). 


\section{Economic and Social Human Rights}

Education indicators turned out to be very susceptible to the regular payment of teachers' salaries, allowing schools to function normally from the existing conditions. In 2016 it was also noted the return of teachers' strikes, with students demonstrations in order to claim for the return of classes. Elementary School dropouts indicators, between the beginning and the end of the school year, started to deteriorate again, excepted for Tombali and the maximum ratings in Quinara. In other words, it is confirmed that the right for education is a direct responsibility of the conditions of education policies regarding conflicts that lead teachers to go on strikes at schools. The schools operating conditions are very different and we tried to express this difference by presenting the breadth of the number of students per teacher in each region. We also realize that the political instability that existed in 2014-2016 did not allow the Ministries of Education to perform their task of coordinating/directing the sector, and caused a level of disorganization that shall be reflected at schools, especially if the respective management board do not have the required leadership skills.

Indicators for education:

1. School attendance per elementary school (1st-6th grade), students' sex gender, at the beginning and end of the school year.

2. Number of students per teacher at a school, at the beginning and end of the school year (1st-6th grade).

3. Average distance between the place of residence and a school where there is basic education (1st-6th grade).

Table 1 - Indicators of access to basic education, 1st-6th class, 2016 per region

\begin{tabular}{|c|c|c|c|c|c|c|c|c|c|}
\hline \multirow{3}{*}{$\begin{array}{c}\text { Region } \\
\text { Year }\end{array}$} & \multicolumn{7}{|c|}{ Elementary school students 1st - 6th grade } & \multirow{2}{*}{\multicolumn{2}{|c|}{$\begin{array}{l}\text { Distance between } \\
\text { residence and } \\
\text { elementary school } \\
\text { 1st - 6th class }(\mathrm{km})\end{array}$}} \\
\hline & \multicolumn{2}{|c|}{$\begin{array}{l}\text { Male dropout } \\
\text { (percent) }\end{array}$} & \multicolumn{2}{|c|}{$\begin{array}{l}\text { Female dropout } \\
\text { (percent) }\end{array}$} & \multicolumn{2}{|c|}{$\begin{array}{c}\text { Student per Teacher } \\
\left(\mathrm{n}^{0}\right)\end{array}$} & \multirow{2}{*}{\begin{tabular}{|c|}
$\begin{array}{c}\text { Proportion } \\
\mathrm{M} / \mathrm{F}\end{array}$ \\
$\mathbf{2 0 1 6}$ \\
\end{tabular}} & & \\
\hline & 2015 & 2016 & 2015 & 2016 & 2015 & 2016 & & 2015 & 2016 \\
\hline Bafatá & 0,6 & 1,6 & 6,0 & 6,6 & 61 & 66 & 1,1 & 6,0 & 8,0 \\
\hline Biombo & 10,5 & 16,4 & 11,4 & 16,1 & 30 & 28 & 1,1 & 3,0 & 4,0 \\
\hline Cacheu & 6,4 & 9,2 & 5,1 & 10,2 & 36 & 33 & 1,1 & 2,0 & 3,0 \\
\hline Gabu & 0,7 & 2,9 & 0,8 & 4,7 & 71 & 67 & 1,1 & 0,70 & 0,3 \\
\hline Oio & 3,5 & 7,4 & 4,8 & 6,3 & 51 & 45 & 1,5 & 2,0 & 2,0 \\
\hline Quinara & 1,0 & 13,7 & 2,3 & 15,1 & 49 & 43 & 1,3 & 0,78 & 0,7 \\
\hline Tombali & 0,5 & $-1,0$ & 1,1 & $-0,7$ & 56 & 43 & 1,2 & 2,0 & 2,5 \\
\hline SAB & 7,0 & 7,2 & 2,8 & 8,7 & 34 & 32 & 1,0 & 1,0 & 0,95 \\
\hline
\end{tabular}

Source: Observatory of Rights, Bissau, 2015 and 2016

The data collected from twenty two schools in three regions with 7th-9th grade students does not allow very clear conclusions when compared to schools that have 1st-6th grade students. The number of students per teacher is lower in Biombo and Cacheu but similar in SAB. It is alarming that the dropout rates are higher in 7th-9th grade students than in the previous ones, except for the male students in Biombo. It was seen that the thesis that says a lower number of students per teacher has as consequence a higher quality in the education and less abandonment was not confirmed in this brief experiment, in 2016. Considering that in the capital the teachers are better the families, from all regions, search for such professionals, which increases the number of students per teacher, in the SAB. 
Table 2 - Indicators of access to elementary education, 7th-9th grade, 2016 per region

\begin{tabular}{|c|c|c|c|c|}
\hline \multirow[b]{2}{*}{ Region } & \multicolumn{4}{|c|}{ Students from 7 th to 9 th grade } \\
\hline & $\begin{array}{c}\text { Male } \\
\text { dropout }\end{array}$ & $\begin{array}{l}\text { Female } \\
\text { dropout }\end{array}$ & $\begin{array}{c}\text { Student per } \\
\text { teacher, at the } \\
\text { beginning }\end{array}$ & $\begin{array}{c}\text { Students per } \\
\text { teacher, in } \\
\text { the end } \\
\end{array}$ \\
\hline Bafatá & n.i. & n.i. & n.i. & n.i. \\
\hline Biombo & 12,2 & 16,8 & 14 & 12 \\
\hline Cacheu & 16,2 & 12,2 & 7 & 6 \\
\hline Gabu & n.i. & n.i. & n.i. & n.i. \\
\hline Oio & n.i. & n.i. & n.i. & n.i. \\
\hline Quinara & 0,97 & 2,33 & 52 & 51 \\
\hline Tombali & n.i. & n.i. & n.i. & n.i. \\
\hline SAB & 10,4 & 15,2 & 38 & 28 \\
\hline
\end{tabular}

Source: Observatory of Rights, Bissau, 2016

In health indicators, this year has confirmed the variation of data collected in regions where accessibility to health care depends on aid projects related to medicines distribution, free-ofcharge appointments and treatments, and international support to buy equipments and consumables to hospitals and health centers. When these projects do not exist or temporarily cease, the cost of health care rises to levels that force families to make great efforts to have access to them. Those who do not have the financial condition to pay for such costs, eventually find themselves excluded. This situation makes the health sector dependent on international cooperation and puts the people's right to proper health in a very randomly varying position from year to year.

Indicators for Health:

4. Distance between the place of residence and a place, where there is prenatal examination

5. Cost of the first prenatal exam (pass, analysis and examination) by a location, where there is this availability.

6. Cost of five different medicines (malaria, fever, diarrhea, soreness and infant hydration).

7. Cost of appointment, examination/analysis, medicines and serum for severe malaria (three or more levels).

8. Health personnel per hospitals, centers or basic units in a region (doctor, nurse, midwife, health assistant and community health workers). 
Table 3 - Indicators of access to healthcare, 2015 and 2016 per region

\begin{tabular}{|c|c|c|c|c|c|c|c|c|c|c|}
\hline \multirow{2}{*}{ Region } & \multicolumn{2}{|c|}{$\begin{array}{l}\text { Distance between the } \\
\text { place of residence } \\
\text { and a place, where it } \\
\text { can perform a } \\
\text { prenatal exam. }(\mathrm{km})\end{array}$} & \multicolumn{2}{|c|}{$\begin{array}{l}\text { Cost of prenatal } \\
\text { exam (pass, } \\
\text { analysis and } \\
\text { examination) }\end{array}$} & \multicolumn{2}{|c|}{$\begin{array}{c}\text { Days of rice } \\
\text { consumption } \\
\text { equivalent to the } \\
\text { prenatal } \\
\text { consultation cost }\end{array}$} & \multicolumn{2}{|c|}{$\begin{array}{l}\text { Cost of medicines } \\
\text { for malaria, fever, } \\
\text { diarrhea and infant } \\
\text { hydration }\end{array}$} & \multicolumn{2}{|c|}{$\begin{array}{l}\text { Cost of treating } \\
\text { malaria (level } 3 \text { or } \\
\text { more ) }\end{array}$} \\
\hline & 2015 & 2016 & 2015 & 2016 & 2015 & 2016 & 2015 & 2016 & 2015 & 2016 \\
\hline Bafatá & 7 & 7 & 2391 & 1914 & 4,5 & 3,3 & 3692 & 9262 & 4895 & 5961 \\
\hline Biombo & 7,4 & 5 & 3825 & 500 & 6,6 & 0,9 & 3268 & 1596 & 6169 & 4319 \\
\hline Cacheu & 8 & 7 & 2700 & 2762 & 4,8 & 4,9 & 1230 & 825 & 1277 & 2275 \\
\hline Gabu & 5,2 & 6 & 3195 & 3779 & 5,8 & 7,0 & 3079 & 2931 & 17427 & 12941 \\
\hline Oio & 10 & 11 & 1482 & n.i. & 2,6 & n.i. & 5038 & 10988 & 7269 & 8869 \\
\hline Quinara & 10,8 & 12 & 1800 & 1388 & 3,1 & 2,4 & 3361 & 3105 & 15615 & 23930 \\
\hline Tombali & 8 & 7 & 4250 & 3300 & 8,5 & 5,7 & 681 & 559 & 7120 & 3322 \\
\hline SAB & 2,1 & 1,7 & 10054 & 7321 & 17,2 & 13,3 & 5298 & 5522 & 19252 & 26235 \\
\hline
\end{tabular}

Source: Observatory of Rights, Bissau, 2015, 2016

Table 4 - Indicators of access to healthcare and health personnel, 2015 and 2016 per region

\begin{tabular}{|l|l|l|l|l|l|l|l|l|l|l|}
\hline \multirow{2}{*}{ Region } & \multicolumn{3}{|l}{$\begin{array}{l}\text { Inhabitants per } \\
\text { doctor }\end{array}$} & \multicolumn{3}{l}{$\begin{array}{l}\text { Inhabitants per } \\
\text { nurse }\end{array}$} & \multicolumn{3}{l}{$\begin{array}{l}\text { Women per } \\
\text { midwife }\end{array}$} & \multicolumn{2}{l|}{$\begin{array}{l}\text { Health } \\
\text { assistants }\end{array}$} \\
\cline { 2 - 11 } & $\mathbf{2 0 1 5}$ & $\mathbf{2 0 1 6}$ & $\mathbf{2 0 1 5}$ & $\mathbf{2 0 1 6}$ & $\mathbf{2 0 1 5}$ & $\mathbf{2 0 1 6}$ & $\mathbf{2 0 1 5}$ & $\mathbf{2 0 1 6}$ & $\mathbf{2 0 1 5}$ & $\mathbf{2 0 1 6}$ \\
\hline Bafatá & 3684 & 2308 & 3231 & 2121 & 9423 & 9262 & 19092 & 7778 & 244 & 195 \\
\hline Biombo & 24280 & 24280 & 3133 & 2023 & 9858 & 4929 & n.i. & n.i. & 537 & 478 \\
\hline Cacheu & 8750 & 8750 & 2831 & 2790 & 8811 & 8077 & n.i. & 24064 & 535 & 553 \\
\hline Gabu & 30790 & 30790 & 3781 & 3716 & 26504 & 21203 & n.i. & 71843 & 576 & 560 \\
\hline Oio & 16046 & 37441 & 4405 & 9767 & 8005 & 16009 & 8640 & 44929 & 808 & 2080 \\
\hline Quinara & 12722 & 21203 & 1078 & 1928 & 5891 & 6185 & n.i. & n.i & 167 & 1010 \\
\hline Tombali & 15823 & 13563 & 1899 & 1862 & 23495 & 15663 & n.i. & 23735 & n.i. & n.i. \\
\hline SAB & 4459 & 5968 & 1029 & 1830 & 1977 & 2485 & 14920 & 64652 & 4910 & n.i. \\
\hline
\end{tabular}

Source: Observatory of Rights, Bissau, 2015, 2016

Regarding the indicators of justice, the conditions of imprisonment and detention (ventilation, cover, dormitory, access to water and food, cell area per prisoner/arrested person) remain in deplorable state in any region. In the two prisons of the country, the conditions are more acceptable, except for the area of detention in Mansoa where it requires the prisoners to sleep in shifts, as it happens in some detention centers, in SAB and other regions. As a result of the fragility of the judicial system, the population, mainly, continues to turn to the traditional authorities and to police officers, in order to resolve complaints of cattle theft. It is possible to consider that the courts are a last resort due to the distance, costs and slowness.

Indicators for Justice:

14. Distance from the residence to a first-instance court.

15. Number of imprisoned people per cell area, sex gender and incarceration center.

16. Number of imprisoned people per cell area and sex gender in the Bafatá and Mansoa prisons. 
17. Conditions of cell areas in incarceration centers and in prisons (ventilation, dormitory, cover, access to water and to food).

18. Entity whom people believe to solve cattle theft (traditional, police or court).

Table 5 - Indicators of access to justice, distance from residence to a first-instance court (km)

\begin{tabular}{|l|l|l|l|l|l|}
\hline Region & $\mathbf{2 0 1 5}$ & $\mathbf{2 0 1 6}$ & Region & $\mathbf{2 0 1 5}$ & $\mathbf{2 0 1 6}$ \\
\hline Bafatá & 16 & 17 & Oio & 17 & 18 \\
\hline Biombo & 15 & 20 & Quinara & 50 & 52 \\
\hline Cacheu & 15 & 14 & Tombali & 33 & 33 \\
\hline Gabu & 29 & 39 & SAB & 2 & 2,5 \\
\hline
\end{tabular}

Source: Observatory of Rights, Bissau, 2015 and 2016

Table 6 - Indicators of access to justice, incarceration centers and prisons per conditions of detention zones

\begin{tabular}{|c|c|c|c|c|c|c|c|c|c|c|c|c|}
\hline \multirow{3}{*}{$\begin{array}{c}\text { Type of } \\
\text { condition }\end{array}$} & \multicolumn{10}{|c|}{ Condition Rank } & \multirow{2}{*}{\multicolumn{2}{|c|}{ Total }} \\
\hline & \multicolumn{2}{|c|}{ Good } & \multicolumn{2}{|c|}{ Fair } & \multicolumn{2}{|c|}{ Average } & \multicolumn{2}{|c|}{ Poor } & \multicolumn{2}{|c|}{ Severe } & & \\
\hline & 2015 & 2016 & 2015 & 2016 & 2015 & 2016 & 2015 & 2016 & 2015 & 2016 & 2015 & 2016 \\
\hline Ventilation & 5 & 7 & 5 & 0 & 12 & 13 & 17 & 18 & 0 & 0 & 39 & 38 \\
\hline Roof cover & 24 & 15 & 7 & 9 & 0 & 0 & 8 & 14 & 0 & 0 & 39 & 38 \\
\hline Dormitory & 0 & 0 & 0 & 0 & 1 & 0 & 22 & 24 & 16 & 14 & 39 & 38 \\
\hline
\end{tabular}

Source: Observatory of Rights, Bissau, 2015, 2016

Table 7 - Indicators of access to justice, incarceration center and prisons per access of water and food

\begin{tabular}{|c|c|c|c|c|}
\hline \multirow{2}{*}{ Items } & \multicolumn{2}{|c|}{2015} & \multicolumn{2}{c|}{2016} \\
\cline { 2 - 5 } & $\begin{array}{c}\text { Not } \\
\text { present }\end{array}$ & Present & $\begin{array}{c}\text { Not } \\
\text { present }\end{array}$ & Present \\
\hline Free access to water & 39 & 0 & 37 & 1 \\
\hline Food & 39 & 0 & 38 & 0 \\
\hline
\end{tabular}

Source: Observatory of Rights, Bissau, 2015 and 2016

Note: Free access to water is considered when prisoners can drink without relying upon the guards for permission. Access to food is considered when prisoners can cook/heat food, which comes from outside the detention center. No detention center provides any food.

As for the indicators of housing, energy, water and sanitation this year of 2016 the pattern became more indefinite than the previous years. For both illuminated and improved houses, there were regions where the numbers increased and others where they decreased. Photographs as a source of information reveal an increase in the use of solar panels even in houses with more modest roof tops and walls. Access to regular water is dependent on wells, generally, without proper processing. Although there are photographs of fountains with great potential for treating water, in two regions, these are still scarce. Sanitation reveals the lack of 
control in the management of the waste destination that the population produces, predicts atrocious consequences for the environment and biodiversity, in a future that families would consume more.

Indicators for housing, energy, water and sanitation:

9. Number of people per room, in a village or neighborhood.

10. Number of houses where there can be seen improvements, per village or neighborhood.

11. Number of traditional improved wells with pump running and piped water per village or neighborhood.

12. Number of houses with access to electric lamps powered by energy from any source, at night (usually electric grid, generator or solar panel), per village or neighborhood.

13. Destination of household waste.

Table 8 - Indicators for housing, water, energy and sanitation

\begin{tabular}{|c|c|c|c|c|c|c|c|c|}
\hline \multirow{2}{*}{ Region } & $\begin{array}{c}\text { Percentage of } \\
\text { improved } \\
\text { houses, out of } \\
\text { the surveyed } \\
\text { ones }\end{array}$ & $\begin{array}{c}\text { Punning wells } \\
\text { (in a percent } \\
\text { of the total in } \\
\text { the region) }\end{array}$ & $\begin{array}{c}\text { Traditional } \\
\text { wells (in a } \\
\text { percent of the } \\
\text { total in the } \\
\text { region) }\end{array}$ & $\begin{array}{c}\text { Percentage of } \\
\text { houses powered } \\
\text { by electric } \\
\text { energy, out of } \\
\text { the surveyed } \\
\text { ones }\end{array}$ & \multicolumn{2}{|c|}{$\begin{array}{c}\text { Highest percent of waste } \\
\text { destination }\end{array}$} \\
\hline & 2015 & 2016 & 2016 & 2016 & 2015 & 2016 & 2015 & 2016 \\
\hline Bafatá & 41,6 & 24 & 15 & 15 & 15,0 & 22 & $\begin{array}{c}\text { Incineration } \\
(43,4)\end{array}$ & $\begin{array}{c}\text { Incineration } \\
(35,6)\end{array}$ \\
\hline Biombo & 19,9 & 21 & 29 & 29 & 8,2 & 15 & $\begin{array}{c}\text { Incineration } \\
(48,0)\end{array}$ & $\begin{array}{c}\text { Incineration } \\
(58,0)\end{array}$ \\
\hline Cacheu & 39,1 & 33 & 7 & 7 & 7,1 & 11 & $\begin{array}{c}\text { Inhabited } \\
\text { sewers } \\
(71,1)\end{array}$ & $\begin{array}{c}\text { Inhabited } \\
\text { sewers } \\
(91,6)\end{array}$ \\
\hline Gabu & 21,8 & 14 & 21 & 21 & 18,8 & 15 & $\begin{array}{c}\text { Incineration } \\
(53,9)\end{array}$ & $\begin{array}{c}\text { Incineration } \\
(91,6)\end{array}$ \\
\hline Oio & 12,9 & 16 & 23 & 23 & 11,3 & 23 & $\begin{array}{c}\text { Incineration } \\
(66,0)\end{array}$ & $\begin{array}{c}\text { Incineration } \\
(54,9)\end{array}$ \\
\hline Quinara & 22,7 & 34 & 16 & 27 & 16,7 & 28 & $\begin{array}{c}\text { Inhabited } \\
\text { sewers } \\
(63,3)\end{array}$ & $\begin{array}{c}\text { Inhabited } \\
\text { sewers } \\
(71,4)\end{array}$ \\
\hline Tombali & 50,8 & 44 & 7,8 & 7,8 & 21,7 & 21 & $\begin{array}{c}\text { Incineration } \\
(43,1)\end{array}$ & $\begin{array}{c}\text { Inhabited } \\
\text { sewers } \\
(57,1)\end{array}$ \\
\hline SAB & 54,3 & 64,5 & 27,3 & 27,3 & 66,7 & 67,2 & $\begin{array}{c}\text { Evacuation } \\
(43,7)\end{array}$ & $\begin{array}{c}\text { Incineration } \\
(48,0)\end{array}$ \\
\hline
\end{tabular}

Source: Observatory of Rights, Bissau, 2015 and 2016

In the indicators of livelihood, if we consider that a family have more access to sustenance because they have three home daily meals a day, only the families in Gabu shall be close to unanimity of three meals a day (95 percent and 99 percent), in 2015 and 2016. Except this region, in the $\mathrm{SAB}$ there is a simple majority of this number of meals. Biombo and Quinara regions are the worst. On the contrary, if we consider families that have a single meal ("a shot" in Guinean slang) as being the poorest and with less access to subsistence, Biombo will be much worse than any other region. SAB, Oio and Cacheu regions will have a significant amount of families, with access to one meal a day. 
The evolution, of the total families, from 2015 to 2016, is expressed by the increase of the percentage of three and four meals and decreasing those of one and two. In general, this indicator allows us to affirm there has been an evolution of the total of the families, although more evident those with a male head of the family, that moved to the categories with the largest number of meals.

Indicator for the livelihood:

19. Number of home daily meals per family

Table 9 - Families, separated by sex gender of the head of the family, per number of daily meals.

\begin{tabular}{|c|c|c|c|c|c|}
\hline \multirow{2}{*}{$\begin{array}{l}\text { Sex gender of } \\
\text { the head of } \\
\text { the family }\end{array}$} & \multicolumn{4}{|c|}{ Number of meals } & \multirow{2}{*}{ Year } \\
\hline & 1 & 2 & 3 & 4 & \\
\hline $\begin{array}{c}\text { Male } \\
\text { percent }\end{array}$ & 14,5 & 42 & 43,2 & 0,3 & 2015 \\
\hline percent & 13,9 & 38,1 & 46,7 & 1,3 & 2016 \\
\hline $\begin{array}{l}\text { Female } \\
\text { percent }\end{array}$ & 22,5 & 45,8 & 31,7 & 0 & 2015 \\
\hline percent & 20,4 & 46,1 & 33,1 & 0,4 & 2016 \\
\hline Total & 16 & 42,6 & 41,3 & 0,1 & 2015 \\
\hline percent & 15,2 & 39,6 & 43,6 & 1,6 & 2016 \\
\hline
\end{tabular}

Source: Observatory of Rights, Bissau, 2015 and 2016

By elaborating a general index with these indicators, according to the methodology already explained, and bearing in mind that only the last two years are comparable, we will have a relative rank of the regions of Guinea-Bissau.

Table 10 - Ranking of regions, according to the indicators collected

\begin{tabular}{|c|c|c|c|c|c|}
\hline Regions & 2015 & 2016 & Regions & 2015 & 2016 \\
\hline Oio & $1^{\underline{o}}$ & 40 & Cacheu & $5^{0}$ & $2^{\circ}$ \\
\hline SAB & $2^{\circ}$ & 50 & Gabu & 5o & 70 \\
\hline Biombo & 3 o & $3^{\circ}$ & Bafatá & 60 & 60 \\
\hline Tombali & $4^{\circ}$ & $1^{0}$ & Quinara & $7^{\circ} \underline{0}$ & $8^{\circ}$ \\
\hline
\end{tabular}

Source: Observatory of Rights, Bissau, 2015 and 2016

This synthesis index surprises when it comes to the progress of the capital - the SAB - which worsens from 2015 to 2016 while Tombali improves in several ranks. Biombo, Gabu, Bafatá and Quinara remain steady. The explanation is related to health indicators (worse ones in SAB and better ones in Tombali) and to the susceptibility towards more severe educational strikes in the $\mathrm{SAB}$, than in other regions. By analysing these indicators, we believe there is greater equality on the existence of electricity, which changes the relative rankings of the regions.

\section{CONCLUSIONS}

The instability of operating governments for presidential nominations, of the National People's Assembly suspension, and of the conflict between political parties and the presidency of the Republic is not in favor that the economic and social policies contained in the program presented to the international partners in Brussels in 2014 (Governo [5]), which has been widely supported, could actually be implemented, even if following governments keep this text as legitimate. 
The instability results in lack of motivation and funding for the country, and as a consequence many ministries are inactives and do not take any concrete policy measures. As long as there is no government which the population believes to be stable, there will be many public facilities (such as schools, hospitals and even electricity) that will remain uncertain due to their dependency on ministries decisions and on international aid. Such situation will not allow people to develop the confidence needed for them to make decisions about their private, public, economic and social life.

It is not intended to create long-term strategic scenarios in this paper, but rather a short-term perspective with possible consequences on Human Rights. For the long-term scenarios the best texts are still from INEP, (1996), Guinea- Bissau, 2025, Djitu Tem, Long-term National Prospective Studies, INEP/NLTS, Guinea-Bissau and Sangreman, C., Júnior, F., Zeverino G. and Barros, M. (2008) Guinea-Bissau (1994-2005). A Social study of electoral motivations in a fragile State, Lusotopie, XV (1). The CEDEAO proposals - the so-called Conakry Agreement of October, 2016 - of a government including all parties (PAIGC, PRS, Other parties and dissidents) have shown to be absolutely unfeasible. Due to this political instability we do not think that there will be progress until general elections for presidency and parliament, and we can only think of three possible short-term negative scenarios and a fourth, more positive, until the end of the legislature:

\section{First: Banality of chaos}

The trivialization occurs in a scenario where there is no military intervention on the fringes of the law, so that political actors incapacity perpetuates itself and leads to instability. The population carry on living and thinking more and more about their lives in an environment of chaotic institutions. Even if following governments keep the development plan that the first government after elections in 2014 has presented, with an increasing substitution of the State in the dialogue and implementation of development programs by outsourcing for NGOs and international companies (which only respond to the external financier), the international community will maintain some cooperation and financial support, however they will hardly provide the amounts promised in Brussels. In this scenario the economic and social human rights promotion by public institutions is fragile and independent of the sovereignty ones, can restrain this tendency from developing into one of the most authoritative and/or dictatorial environments.

\section{Second: Presidential rule}

If the president manages to form an obedient government recognized by the parliament, with a legal Assembly that can approve budgets, a government and legislation program, he would be able force his view on the logic of exercising political power and restore the same authoritarian regime that previous presidents used to have. He would take upon himself the functions of the president and the prime minister, as it happens in other countries of the sub region. By eliminating the balance-based model of governance which Guinea-Bissau began to implement in 2014, such a regime could have a negative effect on first-generation human rights - freedom and civic and political rights - which would eliminate the most revealing points of criticism through dismissing and replacing those people responsible in direct and indirect public administration. This situation correlate with some unlawfully repression on elements mainly, from the PAIGC, from the media that the newspapers publish, from the economic, social and cultural rights.

\section{Third: Military intervention}

Military leaders may conclude that an intervention outside the institutional scope would eliminate instability (what Manuel dos Santos member of the central board of PAIGC and one of 
the few freedom fighters commander still alive called "a good military coup because it serves the society", May 2017 to a Portuguese newspaper) which could lead to general elections. From the previously carried out analysis, the current social groups do not seem to have any advantages in such a scenario that would deprive them of all international support and put them into a similar situation to the period between 2012 and 2014, with even more difficult duration and consequences to predict. Within this scenario, Human Rights would be as jeopardized as in 2012. Income and activity sources, such as drug trafficking and opposing contracts to environment and biodiversity, would increase again, partly, due to completely dysfunctional institutions arranged where violations increase.

\section{Four: Guinean bipartisanship}

We believe there is a fourth scenario that, without interposing the legislature, and moderately contributing to improve the confidence and image of the political class among the population, could, heretofore, create a more positive social and political environment, along with safeguarding accessible human rights. Despite the significant electoral strength and the internal conflicts that afflict both the PAIGC and the PRS, they can come to an agreement in which a governance pact could be arranged envisioning the progress towards a party transposition, as it occurs in many countries. A scenario of long-lasting stability might be possible, although inclined to reduce the significance of small political parties, if the pact mentioned above takes into account two thesis: firstly, the main source of public resources will still be external for many years (International Public Assistance for Development, which is accessed through state institutions or NGOs, or donations from partner states) and secondly, by considering a process whereby the party that loses the elections is not excluded from access to these channels. Such a pact would allow the current and future presidential function to evolve into a less interventionist model of governance. Ultimately, it would join the existing social groups in the areas of economic and social policy that promote development, and keep Human Rights of different generations like education, health, justice, proper-functioning institutions of sovereign power, unbiased regulation of economic activity and a republican presence of the military and armed-forces.

\section{References}

Barros, M., Júnior, F., Sangreman, C. e Zeverino G.,2008. Guiné - Bissau (1994-2005). Um estudo social das motivações eleitorais num Estado frágil. Lusotopie, XV (1). Bordeaux.

URL:http://pascal.iseg.utl.pt/ cesa/index.php/menupublicacoes/working-papers/130

Cardoso, C., 1996. Classe política e transição democrática na Guiné - Bissau. Pluralismo político na Guiné-Bissau, uma transição em curso. INEP, Bissau.

Cabral, Amílcar., 1974. Textos políticos. Afrontamento, Lisboa.

Ceesay, H.,2016. Guinea-Bissau: The "narco state" and the impact on Institutions in Guinea-Bissau and Countries in the sub-Region. Chabal, P. and Green, T. (orgs) (2016), Guinea-Bissau, micro-state to "narco-state. C.Hurst \& Co. (Publishers) Ltd., London.

Forrest, J.B., 2003. Lineages of state fragility: rural civil society in Guinea-Bissau, Ohio University Press.

Governo, 2015. Plan Stratégique et operationnel, 2015-2020 “Terra Ranka”. Bissau.

Green, M., 2001. What we talk about when we talk about indicators: current approaches to Human Rights measurement. Human Rights quarterly, vol. 23, no. 4, November 2001, The Johns Hopkins University Press.

Lopes, C., 1999. Kaabundé - Espaço, território e poder na Guiné - Bissau, Gâmbia e Casamance pré - coloniais. Afrontamento, Porto.

Manitese, 2016. A função de reabilitação da pena, uma perspectiva para a Guiné - Bissau, Bissau.

Ministério da Economia, do Plano e Integração, 2009. Recenseamento Geral da População e Habitação, edição PNUD, UNFPA, ABC, Bissau.

Osiatynski, W., 2009. The limits of Human Rights, Cambridge University Press. 
Sangreman, C., 2016 and 2017. Observando Direitos na Guiné - Bissau, educação, saúde, habitação, água, energia, justiça e meios de subsistência. Projeto Observatório de Direitos. ACEP, LGDH e CEsA, Lisboa e Bissau.

Santos, M., 1989. Guiné - Bissau : a formação da Nação. A Construção da Nação em África, colóquio INEP/CODESRIA/UNITAR, INEP. Bissau.

Semedo, Odete (org), 2016. Carmen Maria de Araújo Pereira, Os meus três amores. INEP, Kebur, Bissau.

Yasmine Cabral, 2015. Quadro legal dos Direitos Humanos na Guiné-Bissau. Augusta Henriques e outros, Desafios ora di diritu. Projeto Casa dos Direitos, ACEP, Lisboa.

United Nations Office of the High Commissioner for Human Rights, 2012. Indicateurs des Droits de l'Homme: Guide pour mesurer et mettre en oeuvre, Genéve e New York.

\title{
Reference
}

Carlos Sangreman, Fátima Delgado and Luis Vaz Martins, Guinea-Bissau (2014 - 2016). An empirical study of economic and social human rights in a fragile state.

\begin{abstract}
i According to the OCDE Fragile State concept, <www.oecd.org/cad/etatsfragiles>.
ii That, in spite of continuing to have more localized conflicts until 1936, it only ended in 1915, when the Portuguese troops of Teixeira Pinto with the help of the men under the leadership of wolof Abdul Injai, some other ethnic groups and a cuanhama contingent came specifically from Angola defeat allied pepel ethnicity and the "grumetes", due to the Guinean ethnicities failure to unite themselves to create military power equivalent to the 1600 infants - 284 casualties - and 109 horses - 26 casualties - gathered for the campaign (Report of post operations against pepel and revolted grumetes of the island of Bissau. Captain Teixeira Pinto, in 1915). See also Silva, Armando Tavares da, 2016. The Portuguese presence in Guinea, Political and Military History, 1878-1926. Caminhos romanos \& author, Lisbon and Amado, Leopoldo, 2011, Colonial War and War of National Liberation 1950-1974: the case of Guinea Bissau, IPAD, Lisbon.
\end{abstract}

iii The only publication with an unsuccessful narrative of PAIGC that we know of is Pereira, J.A., 2015. PAIGC facing the dilemma Cabo-Verdiano (1959-1974), Campo Campo da Comunicação. Lisbon, about the PAIGC's clandestine anti-colonial action in Cabo Verde which led the former party leader Pedro Pires to write a violent preface against the author for treating with the same credibility the archives of PAIGC and those of political colonialist police. If we look for criticisms in the leadership of Amílcar Cabral or other leaders during the fight for independence by members or even former PAIGC members, we find complete scarcity and unreliability. Mario Sissoko`s interview, a former party official in Conacry, to the Guinean newspaper "The Democrat" of September 28, 2016, is the only one we know that seems to have some documentary and testimonial base besides political colonial Portuguese police PIDE archives.

iv Using the concept of "anti-fragile" from Taleb, Nassim Nicholas, 2014, in Anti fragile Things that benefit from disorder.

v Between 2000 and 2003 the president favored the placement of people from ethnicity balantas in public jobs at an unprecedented level, putting into practice the practices of the leaders who place relatives or close people even without competences as one of the most prestigious leaders of the PAIGC, Carmen Pereira, so well synthesized in Semedo [13].

vi According to INE from Bissau, in the 2009 census the religions / beliefs present in the population are animism (14,9 percent), mainly Sunni Islam (45,1 percent) and Christianity (22,1 percent). Note that a high percentage of the population did not respond to this question (15,9 percent). According to inquirers the origin of these nonresponses would be people who are animists, but do not consider these beliefs a religion. Barros and Sarró have an interesting article about the mixture of religions in Guinean society at the family and social level (Chabal and Green [7]), which contributes to explain these results.

vii Between 1974 and 2016 Guinea Bissau had ten presidents, among interim, elected and nominated by PAIGC (Luís Cabral, Nino Vieira, Carmen Pereira, Veríssimo Seabra, Raimundo Pereira, Henrique Rosa, Malam Bacai Sanhá, Kumba Yala, Serifo Namadjo and João Mário Vaz), and two military commanders who held equivalent positions (Ansumane Mané and Mamadu Turé Kuruma).

viii The detention center of the Judicial Police in Bissau is more similar to a preventive prison in the judicial process than an incarceration center. Moreover, it is called a "preventive jail" where prosecuted people await for trial (see Manitese [9]). 